Article

\title{
Smart Injectable Self-Setting Monetite Based Bioceramics for Orthopedic Applications
}

\author{
Naresh Koju ${ }^{1}$, Prabaha Sikder ${ }^{1} *$ (D) Bipin Gaihre ${ }^{2}$ and Sarit B. Bhaduri ${ }^{1}$ \\ 1 Department of Mechanical Industrial and Manufacturing Engineering, The University of Toledo, \\ Toledo, OH 43606, USA; naresh.koju@gmail.com (N.K.); sarit.bhaduri@gmail.com (S.B.B.) \\ 2 Department of Bioengineering, the University of Toledo, Toledo, OH 43606, USA; \\ bipin.gaihre@rockets.utoledo.edu \\ * Correspondence: james.sikder@gmail.com; Tel.: +1-567-200-1995
}

Received: 22 June 2018; Accepted: 18 July 2018; Published: 22 July 2018

\begin{abstract}
The present study is the first of its kind dealing with the development of a specific bioceramic which qualifies as a potential material in hard-tissue replacements. Specifically, we report the synthesis and evaluation of smart injectable calcium phosphate bone cement (CPC) which we believe will be suitable for various kinds of orthopedic and spinal-fusion applications. The smart nature of this next generation orthopedic implant is attained by incorporating piezoelectric barium titanate (BT) particles into monetite-based (dicalcium phosphate anhydrous, DCPA) CPC composition. The main goal is to take advantage of the piezoelectric properties of BT, as electromechanical effect plays a vital role in fracture healing at the defect site and bone integration with the implant. Furthermore, radiopacity of BT would help in easy detection of the CPC presence at the fracture site during surgery. Results reveal that BT addition favors important properties of bone cement such as good compressive strength, injectability, bioactivity, biocompatibility, and even washout resistance. Most importantly, the self-setting nature of the bone cements are not compromised with BT incorporation. The in vitro results confirm that the developed bone-cement abides by the standard orthopedic requirements making it apt for real-time prosthetic materials.
\end{abstract}

Keywords: smart; calcium phosphate; monetite; barium titanate; bioceramics; orthopedics

\section{Introduction}

This paper reports the development of a new generation, smart, injectable calcium phosphate cement (CPC) for orthopedic applications. The "smart" aspect of the compositions is achieved by incorporating piezoelectric materials into the cement. Piezoelectric materials develop surface charges when compressive stresses are applied to them. Research over the last five decades has unequivocally shown that the important bone constituents such as apatite and collagen, both show piezoelectric behavior [1-8]. This coupled electromechanical phenomenon has an important effect on healing of an orthopedic defect as well as integration of bone with an implant. Park et al. conducted in vivo experiments trying to understand the effect of applied electric field in osseointegration of implants [9-12]. The experiments clearly showed the beneficial effects of an applied electric field. Subsequently, they hypothesized that a piezoelectric implant can deliver the same beneficial effect by generating an electric field in situ without the application of an external field. Barium titanate $\left(\mathrm{BaTiO}_{3}, \mathrm{BT}\right)$, one of the most extensively studied piezoelectric material was the obvious candidate of choice for implantation. In the early eighties, Park et al. reported that dense sintered BT implants were able to stimulate bone growth in dog femurs $[13,14]$. The implants were stable in the dog for several months and did not cause cytotoxicity. These initial experiments showed the effective applications of piezoelectric BT in orthopedics. 
However, since those early reports of BT as an implant material, the field did not progress further in terms of materials development. The next phase of development took place after almost two decades with the development of hydroxyapatite-barium titanate (HA-BT) composites. Jianqing et al. developed composites by using conventional sintering and polarized them before implanting into dog jawbones [15]. A clear rationale was not provided as to why there was the need to develop composites, in view of the fact that both HA and BT are piezoelectric, biocompatible but not bioactive. In other words, the constituents did not possess complementary properties. The results showed accelerated bone formation kinetics around HA-BT implants as compared to pure HA [15]. Progressing along the same strategical avenue, Dubey et al. and Prakasam et al. fabricated BT infused HA composites via multi and single-stage spark plasma sintering (SPS) respectively and the results yielded good biomechanical and electrical properties $[16,17]$. Furthermore, when surface charge was generated by electrical poling of such composites, higher cell proliferation was observed on the negatively charged surfaces [18]. In vivo studies revealed no cytotoxic reactions from HA-BT (containing $40 \mathrm{wt} \% \mathrm{BT}$ ) when implanted into the right knee joints of mice [19]. This finding is comparable to that which Park et al. reported earlier. Even porous nanophase HA-BT composites were proven to be potential candidates in the fabrication of piezoelectric orthopedic implants [20]. All of these materials were fabricated via a powder metallurgical process using different types of sintering techniques.

An important question explored in this respect is to evaluate the effect of BT addition into injectable self-setting orthopedic cement compositions. This would eliminate the requirement of the high temperature sintering process and the fabrication of simple shapes, and enable the cement to be injected at the defect site using a minimally invasive procedure. To the best of our knowledge, Carrodeguas et al. reported the preparation of an injectable bone cement consisting of poly (methyl methacrylate) (PMMA) matrix mixed with $\mathrm{BT}$ or strontium titanate $\left(\mathrm{SrTiO}_{3}, \mathrm{ST}\right)[21,22]$. The main idea was to enhance the radio-opacity of the cement with the incorporation of either BT or ST. The cement was injectable and self-setting besides being radio-opaque. This property helps in monitoring the cement flow under fluoroscopy to avoid leakage. However, PMMA compositions possess the usual drawbacks of setting with high exothermicity besides being inert. Furthermore, no attention was paid to the beneficial effects of piezoelectric properties of BT. Summarizing, this literature search shows that there has been no report of a BT containing smart self-setting bioactive CPC, which incorporates all the beneficial properties of its constituents.

The present study is one of the first of its kind to focus on incorporating BT into monetite-based (dicalcium phosphate anhydrous, DCPA) CPC composition. There are two reasons for choosing the DCPA-based CPC composition. First, commercial CPCs can be mainly classified as apatite and brushite (DCPD) cement [23,24]. DCPD resorbs quickly and transforms into a stable apatite phase after in vivo implantation [25]. Furthermore, the release of orthophosphoric acid during the degradation of DCPD to apatite might cause a certain degree of tissue inflammation [24]. On the other hand, DCPA exhibits a much more stable degradation rate and does not transform into hydroxyapatite (HA), thus increasing the chances of higher bone volume formation [26-29]. This makes DCPA a perfect $\mathrm{CPC}$ candidate. Second, our group has a sustained research thrust in developing CPC compositions, especially DCPA. The present work is the next phase of our CPC research, reporting the development of a novel non-exothermic injectable CPC composition incorporating $\mathrm{BT}$ and investigations on its physical, mechanical, electrical properties and their cytocompatibility in vitro.

\section{Materials and Methods}

\subsection{Materials}

Barium titanate (IV) $\left(\mathrm{BaTiO}_{3}, 99.5 \%\right.$, particle size $\left.\leq 2 \mu \mathrm{m}\right)$ and colloidal silica were procured from Sigma-Aldrich (Saint Louis, MO, USA) and used without further modification. The detailed information of colloidal silica is presented in Table 1. Calcium hydroxide $\left(\mathrm{Ca}(\mathrm{OH})_{2},>95 \%\right)$, magnesium hydroxide $\left(\mathrm{Mg}(\mathrm{OH})_{2}, 95 \%\right)$, sodium bicarbonate $\left(\mathrm{NaHCO}_{3},>99.7 \%\right)$ and magnesium oxide $(\mathrm{MgO}$, 
98\%) from Fischer Scientific (Fair Lawn, NJ, USA) and sodium tetraborate decahydrate as known as borax decahydrate $\left(\mathrm{Na}_{2} \mathrm{~B}_{4} \mathrm{O}_{7} \cdot 10 \mathrm{H}_{2} \mathrm{O},>99.5 \%\right)$ from Alfa Aesar (Ward Hill, MA, USA) were used for the preparation of the cement samples.

Table 1. Information on incorporated colloidal silica.

\begin{tabular}{ccccc}
\hline Product & Concentration & Surface Area & pH & Density \\
\hline LUDOX ${ }^{\circledR} \mathrm{HS}-40$ colloidal silica & $40 \mathrm{wt} \%$ suspension in $\mathrm{H}_{2} \mathrm{O}$ & $\sim 220 \mathrm{~m}^{2} / \mathrm{g}$ & 9.8 & $3 \mathrm{gm} / \mathrm{mL}$ at $25^{\circ} \mathrm{C}$ \\
\hline
\end{tabular}

\subsection{Sample Preparation}

\subsubsection{Premixed Powder (PMP) Preparation}

Preparation of $\mathrm{CaP}$ cement (CPC) samples requires a kind of setting solution and premixed powder (PMP). The setting solution was prepared by diluting $78 \mathrm{~mL}$ of o-phosphoric acid $\left(\mathrm{H}_{3} \mathrm{PO}_{4}\right.$, $85 \%$ ) with $12 \mathrm{~mL}$ of Deionized (DI) water placed in an ultrasonic bath, followed by the addition of $12 \mathrm{~g}$ sodium bicarbonate. The preparation of the setting solution is critical in material preparation as it influences the setting time of the fabricated bone cement. For a controlled reaction rate, $3 \mathrm{~g}$ of $\mathrm{NaHCO}_{3}$ was added over an interval of $30 \mathrm{~s}$. The ultrasonic bath was kept running until the setting solution became clear and then was stored in a tightly capped glass bottle. To prepare PMP, initially, $55.2 \mathrm{~g}$ of $\mathrm{Ca}(\mathrm{OH})_{2}$ and $13.8 \mathrm{~g}$ of $\mathrm{Mg}(\mathrm{OH})_{2}$ were mixed homogeneously in a household mixer (KitchenAid Classic 275 W, KitchenAid, MI, USA). After few minutes of mixing, the setting solution was slowly poured into the mixer bowl and allowed to run for another $2 \mathrm{~min}$. The mixer was kept running at the lowest speed for the whole time. At the end of $2 \mathrm{~min}$, then formed chunks were taken out into a glass bowl and placed immediately inside a household microwave (Panasonic $1250 \mathrm{~W}$, Panasonic Appliances, Shanghai, China) and irradiated at 10\% power level (Level 1) for $6 \mathrm{~min}$. This microwave cycle was repeated several times until the chunks became rock-hard. Finally, the rock-hard cement precursors were ground into powder using a mortar and pestle and PMP fine powder $(\geq 250 \mu \mathrm{m})$ was obtained by sieving it through USA Test Sieve (ASTM E11 specification [30]).

\subsubsection{BT Cement Samples Preparation}

Borax decahydrate ( $4 \mathrm{wt} \%$ of PMP), $\mathrm{MgO}(5 \mathrm{wt} \%$ of PMP) and varying amounts of $\mathrm{BT}(0,10$, $20,30,40 \mathrm{wt} \%$ of total powders) were added to $5 \mathrm{~g}$ PMP and mixed homogeneously. Colloidal silica (liquid) was added to the powder mixture phase using a pipette such that the liquid to powder $(\mathrm{L} / \mathrm{P})$ ratio was maintained constant at $0.35 \mathrm{~mL} / \mathrm{g}$. The specimen name along with its compositions are presented in Table 2. After addition of colloidal silica, the mixture was vigorously mixed for $60 \mathrm{~s}$ using a mortar and pestle. Finally, the formed putty was put into cylindrical molds and prepared for various characterizations.

Table 2. Different smart CaP cement compositions.

\begin{tabular}{cccccc}
\hline Cement & PMP $(g)$ & Borax $(\mathrm{g})$ & MgO $(g)$ & BaTiO $_{3}(g)$ & Colloidal Silica $(m L)$ \\
\hline CPC-0 BT & 5 & 0.20 & 0.25 & - & 1.910 \\
CPC-10 BT & 5 & 0.20 & 0.25 & 0.545 & 2.100 \\
CPC-20 BT & 5 & 0.20 & 0.25 & 1.090 & 2.290 \\
CPC-30 BT & 5 & 0.20 & 0.25 & 1.635 & 2.480 \\
CPC-40 BT & 5 & 0.20 & 0.25 & 2.180 & 2.670 \\
\hline
\end{tabular}

\subsection{Setting Time}

The initial and final setting time of the smart CPC-x BT $(x=w t \%$ of BT) cements were obtained using the Gillmore needle method (ASTM C266-89 [31]). Light and thick needle measures the initial setting time while heavy and thin needle measures the final setting time. The initial and final setting 
times were recorded when the needle left an indentation depth less than $1 \mathrm{~mm}$ on the sample surface. Additionally, respective setting times were measured at an interval of $15 \mathrm{~s}$.

\subsection{Mechanical Properties}

Smart CPC-x BT samples with dimensions, $\varnothing 12.5 \mathrm{~mm}$ and height $7 \mathrm{~mm}$, were prepared for mechanical properties evaluation. Cement samples were allowed to set for $24 \mathrm{~h}$ at room temperature. Compression strength testing was carried out on a universal testing machine with the application of $50 \mathrm{kN}$ uniaxial load cell (model 5569, Instron, Norwood, MA, USA). As per the protocol of the American dental association i.e., $0.75 \pm 0.25 \mathrm{~mm} \cdot \mathrm{min}^{-1}$, the crosshead loading rate of $0.5 \mathrm{~mm} \cdot \mathrm{min}^{-1}$ was set [29].

\subsection{Physical Characterizations}

\subsubsection{X-ray Diffraction Analysis}

X-ray diffraction analysis (XRD, Ultima III; Rigaku, The Woodlands, TX, USA) with mono chromated $\mathrm{Cu} \mathrm{K} \alpha$ radiation ( $44 \mathrm{KV}, 40 \mathrm{~mA}$ ) was used to study the phases present in the as-prepared CPC-x BT samples over $2 \theta$ range of $10-60^{\circ}$. MD JADE software 2010 (MDI, Livermore, CA, USA) was employed to identify the respective phases.

\subsubsection{Fourier Transform Infrared Spectroscopy Analysis}

The functional groups present within the samples were identified with Fourier transform infrared spectroscopy (FTIR, UMA-600 Microscope, Varian Excalibur Series, Digilab, Holliston, MA, USA) using an Attenuated total reflection (ATR) diamond crystal. For each sample, 256 scans were performed within the range of 4000 to $700 \mathrm{~cm}^{-1}$.

\subsubsection{Morphological Observation}

Surface morphology of the samples was examined using scanning electron microscope (SEM, S-4800, Hitachi, Tokyo, Japan). All the samples were mounted on SEM stubs with a copper conducting tape and sputter coated for $90 \mathrm{~s}$ before conducting the SEM study.

\subsection{Simulated Body Fluid (SBF) Immersion}

Smart CPC-x BT samples pellets $\left(\varnothing 6.4 \times 3 \mathrm{~mm}^{3}\right)$ were immersed into tightly capped $50 \mathrm{~mL}$ autoclaved bottles filled with $30 \mathrm{~mL} 1.5 \times \mathrm{t}$-SBF. The detailed composition of $1.5 \times \mathrm{t}$-SBF is shown in Table 3 [32]. The bottles containing the SBF immersed samples were placed in a water bath at $37^{\circ} \mathrm{C}$ for 7 days. Moreover, the SBF was replenished every other day in order to keep the ionic compositions constant. After the time period, samples were cleaned under flowing distilled water and thoroughly dried in an air-convection furnace at $60{ }^{\circ} \mathrm{C}$ for further characterization under SEM.

Table 3. Chemical composition of $1.5 \times \mathrm{t}$-SBF.

\begin{tabular}{ccc}
\hline Order & Reagent & Amount (Weight g per L or Volume mL) \\
\hline 1 & $\mathrm{NaCl}$ & 9.8184 \\
2 & $\mathrm{NaHCO}_{3}$ & 3.4023 \\
3 & $\mathrm{KCl}$ & 0.5591 \\
4 & $\mathrm{Na}_{2} \mathrm{HPO}_{4}$ & 0.2129 \\
5 & $\mathrm{MgCl}_{2} \cdot 6 \mathrm{H}_{2} \mathrm{O}$ & 0.4574 \\
6 & $1 \mathrm{M} \mathrm{HCl}$ & $15 \mathrm{~mL}$ \\
7 & $\mathrm{CaCl}_{2} \cdot 2 \mathrm{H}_{2} \mathrm{O}$ & 0.5513 \\
8 & $\mathrm{Na}_{2} \mathrm{SO}_{4}$ & 0.1065 \\
9 & $\mathrm{TRIS}$ & 9.0855 \\
10 & $1 \mathrm{M} \mathrm{HCl}$ & $50 \mathrm{~mL}$ \\
\hline
\end{tabular}




\subsection{Injectability}

Colloidal silica was added to $\mathrm{Na}_{2} \mathrm{~B}_{2} \mathrm{O}_{7} \cdot 10 \mathrm{H}_{2} \mathrm{O}, \mathrm{MgO}$, and varying amounts of PMP and BT to form putty-like materials which were put into syringes (BD Biosciences, San Jose, CA, USA) with a nozzle diameter of $1.36 \mathrm{~mm}$. The nozzle diameter used in the present work lies between gauge $15(1.449 \mathrm{~mm})$ and gauge $16(1.291 \mathrm{~mm})$ and is smaller than the actual needle size used in clinical cement injection [33]. After loading the putty, the plunger of the syringe was propelled manually to examine the injectability of the as-prepared CPC-x BT cement samples. The samples were considered to have certifiable injectability if the cement did not remain inside the syringe during injection.

\subsection{Washout Resistance Test}

As per the Takagi et al. protocols, different composition of cement pastes were prepared, loaded into syringes and then immediately injected into saliva-like solution (SLS) at $37^{\circ} \mathrm{C}$ even before the initial setting time [34]. Immediate injection of cement mimics the real-time orthopedic application and thus is a pragmatic evaluation. SLS was prepared using $1.2 \mathrm{mmol} / \mathrm{L}$ calcium chloride $\left(\mathrm{CaCl}_{2}\right)$, $0.72 \mathrm{mmol} / \mathrm{L}$ monopotassium phosphate $\left(\mathrm{KH}_{2} \mathrm{PO}_{4}\right), 30 \mathrm{mmol} / \mathrm{L}$ potassium chloride $(\mathrm{KCl}), 50 \mathrm{mmol} / \mathrm{L}$ $\mathrm{N}-2$-hydroxyethyl-piperazine- $\mathrm{N}^{\prime}-2^{\prime}$-ethane sulfonic acid (HEPES) buffer and finally its $\mathrm{pH}$ was adjusted to 7 with $0.1 \mathrm{~mol} / \mathrm{L} \mathrm{NaOH}$. The sample was considered to pass the washout resistance test if it did not visibly disintegrate in the SLS for $5 \mathrm{~min}$.

\subsection{Biodegradation}

In order to study the in vitro biodegradation rate of smart CPC-x BT samples $\left(\varnothing 12.5 \times 7 \mathrm{~mm}^{3}\right)$, $1.5 \times \mathrm{t}$-SBF solution was used as the medium. As per the Wu et al. protocol, cement samples, after they had set for $24 \mathrm{~h}$, were immersed in glass bottles containing $1.5 \times \mathrm{t}-\mathrm{SBF}$. The bottles were then placed in a water-bath shaker which maintained $37^{\circ} \mathrm{C}$ and $100 \mathrm{rpm}$. The weight-to-volume ratio of the test specimens were also maintained at $0.2 \mathrm{gm} / \mathrm{mL}$ [35-37]. For over a time span of 7 days, each and every day the samples were retrieved from the SBF solution, cleaned in deionized water, dried at $60^{\circ} \mathrm{C}$ for $2 \mathrm{~h}$, and weighed for any weight loss. The dried coupons were re-immersed into fresh $1.5 \times \mathrm{t}$-SBF solution with repetition of the above-mentioned steps. The biodegradation rate of the coupons at various points of time was calculated using the Equation (1).

$$
\text { Weight loss }=\frac{W_{i}-W_{d}}{W_{d}} \times 100 \%
$$

where, $W_{i}$ represents initial coupon weight, and $W_{d}$ represents dried coupon weight after degradation.

\subsection{In Vitro Cytocompatibility}

\subsubsection{WST-1 Assay}

OB-6 pre-osteoblast cell line and water-soluble tetrazolium (WST-1) assay were used to study the cytocompatibility of the smart cement samples. This is a colorimetric assay based on the conversion of stable tetrazolium salt into soluble formazan by the cellular mechanism that occurs at the cell surface. Hence, the amount of formazan detected directly relates to the number of metabolically active cells. For this assay, sample pellets $\left(\varnothing 6.4 \times 3 \mathrm{~mm}^{3}\right)$ were incubated in complete culture medium for $24 \mathrm{~h}$ at $37^{\circ} \mathrm{C}$ and $5 \% \mathrm{CO}_{2}$ in a 24 well plate, following the extraction ratio of $3 \mathrm{~cm}^{2} / \mathrm{mL}$. In a 96-well plate, 10,000 cells/well were plated and incubated at the same conditions for $24 \mathrm{~h}$. After $24 \mathrm{~h}$, the culture medium on the cell plated 96-well plate was replaced with $100 \mu \mathrm{L}$ of the extracted or conditioned medium (the medium which contained the specimens for $24 \mathrm{~h}$ ). The cells were further cultured in the conditioned media for a period of $24 \mathrm{~h}$ or $72 \mathrm{~h}$ at $37^{\circ} \mathrm{C}$ and $5 \% \mathrm{CO}_{2}$. At specific time points, $10 \mu \mathrm{L}$ (1:10 ratio) of WST-1 reagent was added to wells containing cells/medium and incubated for $4 \mathrm{~h}$ under 
the same conditions. After $4 \mathrm{~h}$, the formation of water soluble formazan was detected at $450 \mathrm{~nm}$ using a SpectraMax 190 microplate reader (Molecular Devices, San Jose, CA, USA).

\subsubsection{Live and Dead Assay}

The viability of pre-osteoblasts (OB-6) attached to the samples was imaged using a Cytation 5 cell imaging multi-mode reader (BioTek, Winooski, VT, USA) after staining them with Live/Dead cell viability kit (Thermofisher Scientific, Waltham, MA, USA) at day 5 . The samples were first kept under UV light for $15 \mathrm{~min}$ followed by incubation with complete cell culture media for $1 \mathrm{~h}$ at $37^{\circ} \mathrm{C}$ and $5 \% \mathrm{CO}_{2}$. The OB-6 cells harvested from the cell-culture dishes were then seeded onto the top of the samples at 30,000 cells/sample. In order to allow the proper attachment of the cells to the sample, $200 \mu \mathrm{L}$ of cell suspension containing 30,000 cells was first added to the samples and incubated at $37^{\circ} \mathrm{C}$ and $5 \% \mathrm{CO}_{2}$ for $3 \mathrm{~h}$. After $3 \mathrm{~h}$, remaining media was added, and the incubation was continued, and the media was changed every third day. On day 5 , the cell-sample construct was moved to the new well and washed twice with 1X PBS. The Live/Dead assay solution containing calcein AM and ethidium homodimer (EthD-1) diluted in 1X Dulbecco's-PBS was added to the samples and incubated for $30 \mathrm{~min}$ at $37^{\circ} \mathrm{C}$. The viable cells attached to the samples were indicated by the green fluorescence of calcein which has been enzymatically converted from calcein AM by live cells. Similarly, the dead cells were indicated by the red fluorescence obtained due to the binding of EthD-1 that entered through the ruptured cells to the nucleic acid.

\subsection{Statistical Analysis}

All the experiments were carried out in triplicate for each composition and the results were represented as mean \pm SD. Statistical analysis of obtained results was carried out using a one-way analysis of variance (one-way ANOVA). To depict statistically different groups Tukey's test with $p<0.05$ was carried out.

\section{Results}

\subsection{Setting Time}

The initial and final setting times for smart $\mathrm{CaP}$ cements with different concentrations of $\mathrm{BT}$ at a constant $\mathrm{L} / \mathrm{P}$ ratio of $0.35 \mathrm{~mL} \cdot \mathrm{g}^{-1}$ are presented in Table 4 . No significant variation $(p>0.05)$ were observed except for $10 \mathrm{wt} \%$ BT samples. The CPC-10 BT samples displayed significantly $(p<0.05)$ lower final setting time when compared to other formulations.

Table 4. Setting time for smart CPCs with various wt \% barium titanate (BT).

\begin{tabular}{ccc}
\hline Cement & Initial Setting Time (min) & Final Setting Time (min) \\
\hline CPC-0 BT & $8.83 \pm 0.72$ & $15.33 \pm 0.24$ \\
CPC-10 BT & $7.58 \pm 0.12$ & $13.67 \pm 0.62 *$ \\
CPC-20 BT & $7.92 \pm 0.42$ & $15.17 \pm 0.51$ \\
CPC-30 BT & $8.08 \pm 0.72$ & $16.33 \pm 0.24$ \\
CPC-40 BT & $8.50 \pm 0.35$ & $15.92 \pm 0.42$ \\
\hline
\end{tabular}

* represents significantly different from rest of the composition.

\subsection{Mechanical Properties}

The results of compressive strength of smart CPC samples with varying wt $\%$ of BT are displayed in Figure 1. All compositions showed similar compressive strength without any significant differences $(p>0.05)$. This indicates the negligible effect of BT addition on compressive strength of CPC cements up to $40 \mathrm{wt} \%$. 


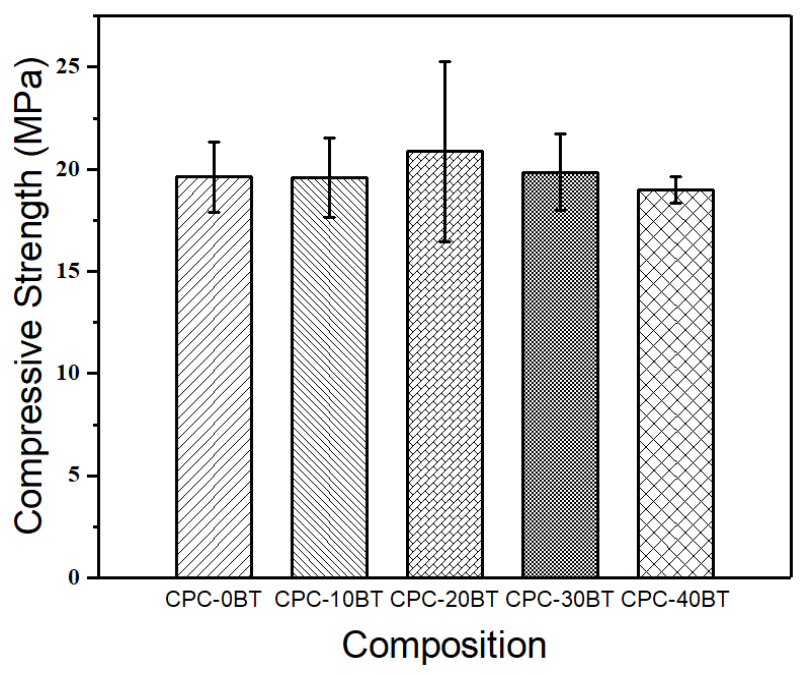

Figure 1. Compressive strengths of different compositions of smart calcium phosphate bone cements (CPCs).

\subsection{Physical Characterizations}

\subsubsection{XRD Analysis}

The self-setting smart CPC-x BT cement samples were crushed into powder used for XRD analysis. The XRD spectra of the respective specimens are shown in Figure 2. All major peaks of CPC-0 BT correspond to monetite (JCPDS PDF\# 97-003-8128). With incorporation of BT into PMP, apart from monetite, new peaks corresponding to barium titanate (JCPDS PDF\# 97-002-7969) were identified. All the XRD peaks of BT showed much higher crystallinity as compared to monetite. The major peak of BT was present at the $2 \theta$ angle of $31.5^{\circ}$ along the plane [110], and its intensity intensified with increasing doping percentage. The $\mathrm{XRD}$ analysis also picked up small traces of newberyite $\left(\mathrm{MgHPO}_{4} \cdot 3 \mathrm{H}_{2} \mathrm{O}\right)$ and calcium dihydrogen phosphate $\left(\mathrm{Ca}\left(\mathrm{H}_{2} \mathrm{PO}_{4}\right)_{2}\right)$.

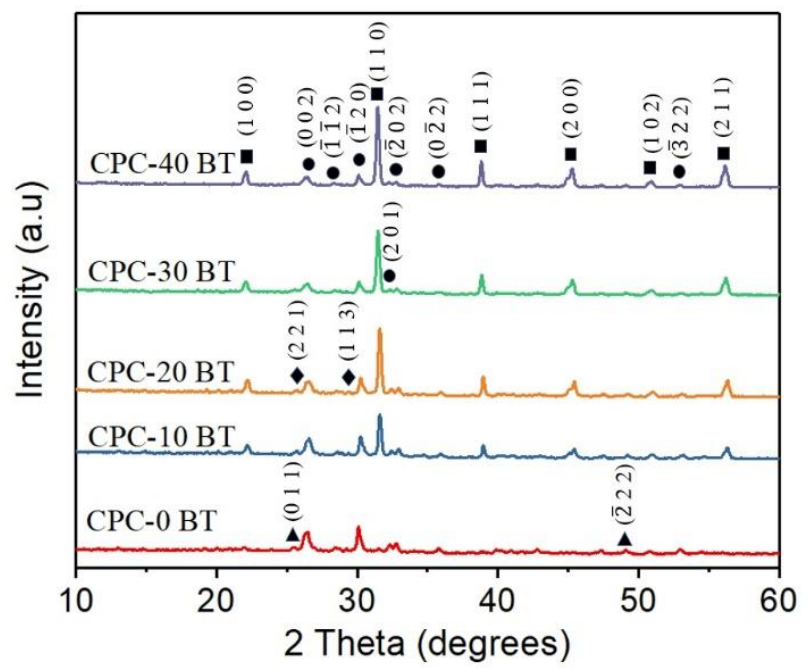

Figure 2. X-ray diffraction (XRD) patterns of $\mathrm{CPC}$ with various wt $\% \mathrm{BaTiO}_{3}$ (' $\mathbf{\boldsymbol { }}$ ' represents barium titanate (BT), ' $\bullet$ ' represents monetite, ' $\checkmark$ ' represents newberyite and ' $\boldsymbol{\Lambda}$ ' represents $\left.\mathrm{Ca}\left(\mathrm{H}_{2} \mathrm{PO}_{4}\right)_{2}\right)$.

\subsubsection{FTIR Analysis}

The FTIR spectra of smart CPCs with different concentration of BT are presented in Figure 3. All samples have similar absorbance spectra with the presence of hydroxyl $\left(\mathrm{OH}^{-}\right)$, phosphate 
$\left(\mathrm{PO}_{4}{ }^{3-}\right)$ /hydrogen phosphate $\left(\mathrm{HPO}_{4}{ }^{2-}\right)$, and carbonate $\left(\mathrm{CO}_{3}{ }^{2-}\right)$ functional groups. $\mathrm{OH}^{-}$groups are observed in the broad stretching band at $3000-3500 \mathrm{~cm}^{-1}$ which corresponds to absorbed water and at $1650 \mathrm{~cm}^{-1}[37,38]$. The $\mathrm{CO}_{3}{ }^{2-}$ bands are located near $1415 \mathrm{~cm}^{-1}$ like all biological apatite [39]. The band at $1020 \mathrm{~cm}^{-1}$ accounts for the stretching mode of the $\mathrm{P}-\mathrm{O}$ bond [40]. The shoulder peaks at 880 and $1060 \mathrm{~cm}^{-1}$ can be attributed to the presence of $\mathrm{PO}_{4}{ }^{3-}$ and /or $\mathrm{HPO}_{4}{ }^{2-}$. The presence of several visible peaks and shoulder in the region of absorbance spectra of the phosphate region (900-1200 $\mathrm{cm}^{-1}$ ) for all CPC-x BT samples implies the crystallinity of monetite even in the presence of BT [38]. In addition to these functional groups, the stretching band at $790 \mathrm{~cm}^{-1}$ corresponding to Si-O-Si (siloxane) group is observed [41].

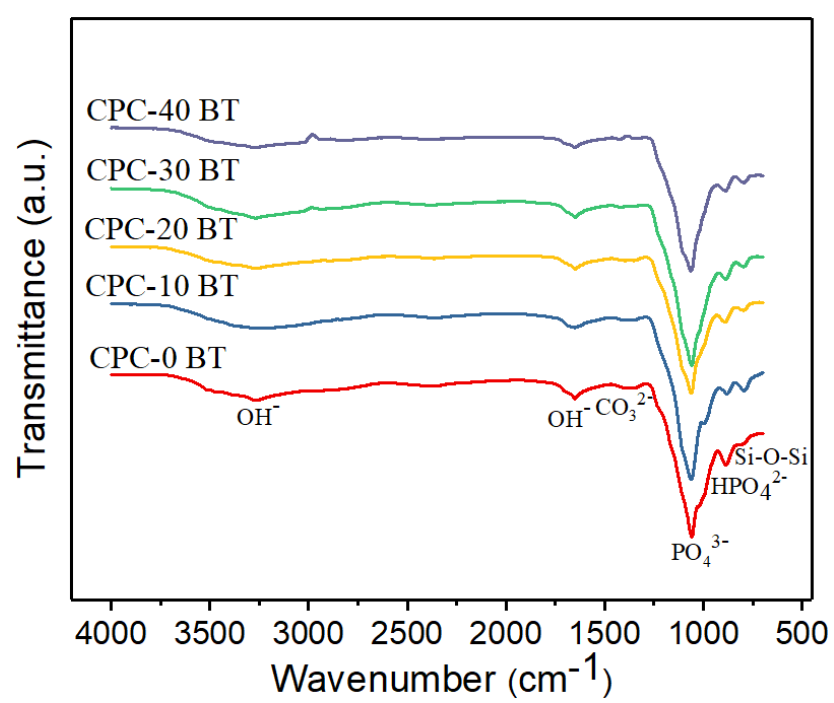

Figure 3. Fourier transform infrared spectroscopy (FTIR) spectra of smart CPC formulation with varying wt \% BT.

\subsubsection{Morphological Observation of Cements}

The SEM images of smart CPC-x BT are shown in Figure 4. All the cement specimens were composed of plate-like DCPA crystals [29,40,42]. Back scattered SEM images projected BT particles (Figure $4 \mathrm{~b}-\mathrm{f}$ ) as white spherical structures distributed homogeneously all over the cement surface area. The surface morphology revealed highly crystalline DCPA structures in CPC specimen especially with 10 and $20 \mathrm{wt} \%$ BT incorporation. Higher magnification image (Figure 4f) shows the morphology of the BT particles assimilated over the CPC matrix. As expected, with increase in BT wt \% in the sample composition, the concentration of white agglomerates also increased.
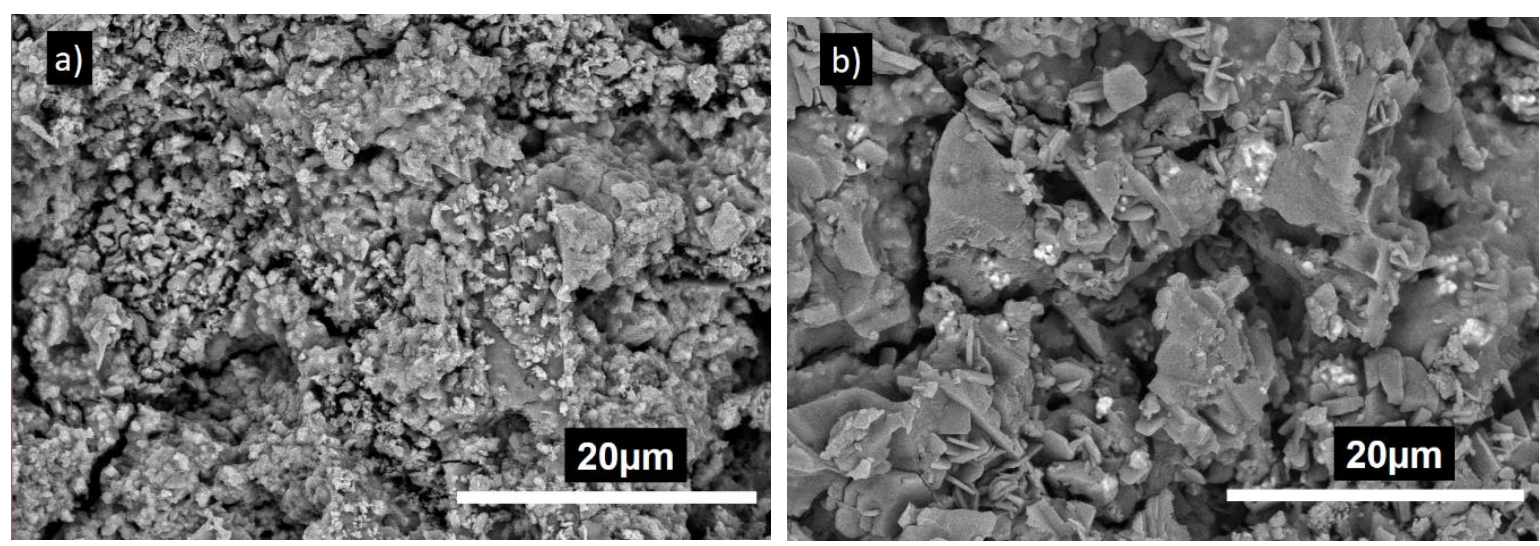

Figure 4. Cont. 

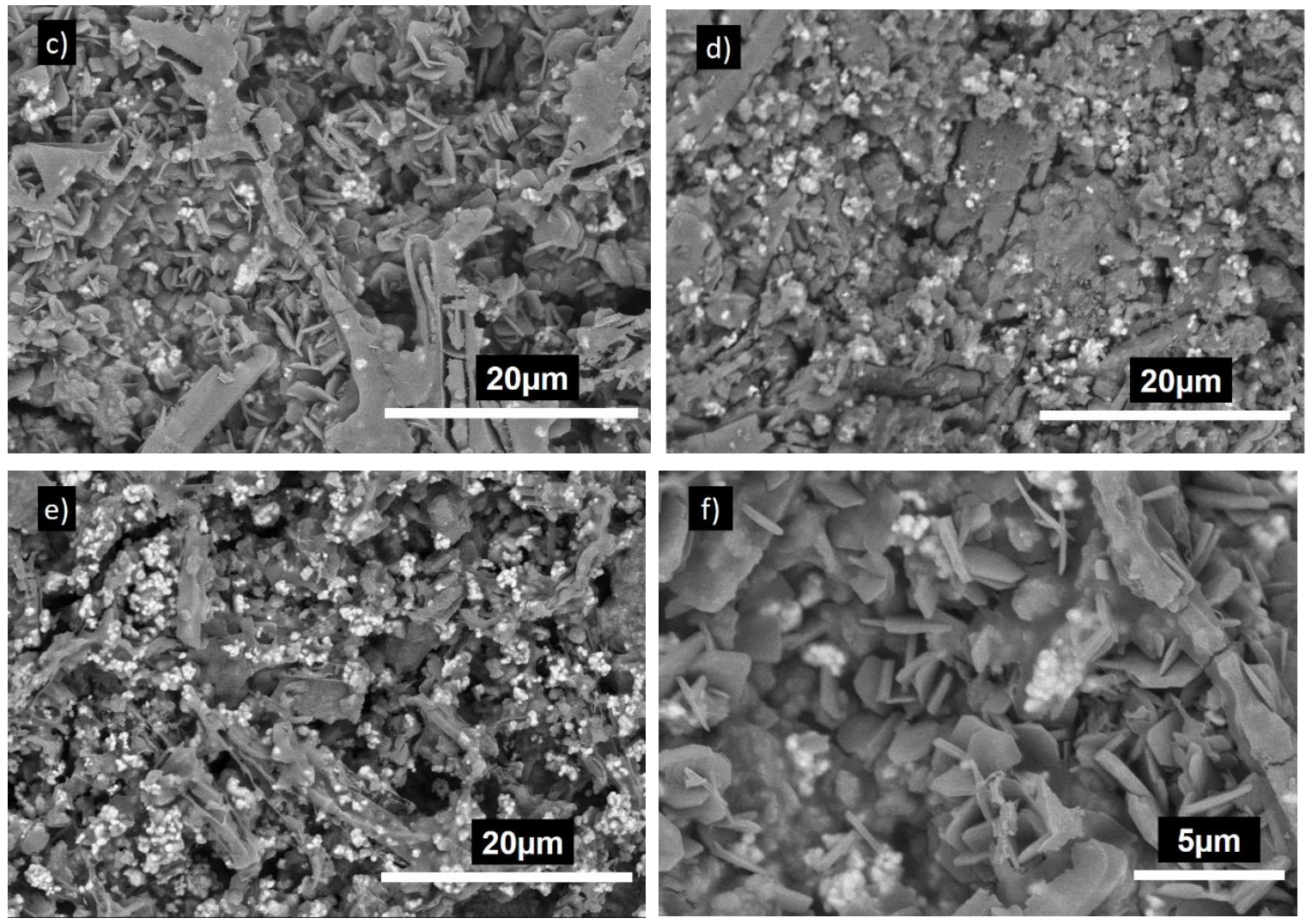

Figure 4. Scanning electron microscopy (SEM) images of (a) CPC-0BT, (b) CPC-10BT, (c,f) CPC-20BT, (d) CPC-30BT, (e) CPC-40BT.

\subsection{Simulated Body Fluid (SBF) Immersion}

The bioactivity of smart CPC with 0, 20 and $40 \mathrm{wt} \%$ BT was examined via an SBF immersion test. After soaking the samples in $1.5 \times \mathrm{t}$-SBF for 7 days, they were characterized by SEM and the results are shown in Figure 5. A uniform dense layer of globular and flower-like structure covered the whole surface of the specimens. With the similarity in morphology they can be identified as apatite. Coatings resulting from SBF immersion usually result in the formation of apatite. Moreover, incorporation of BT did not influence the bioactivity of the samples.
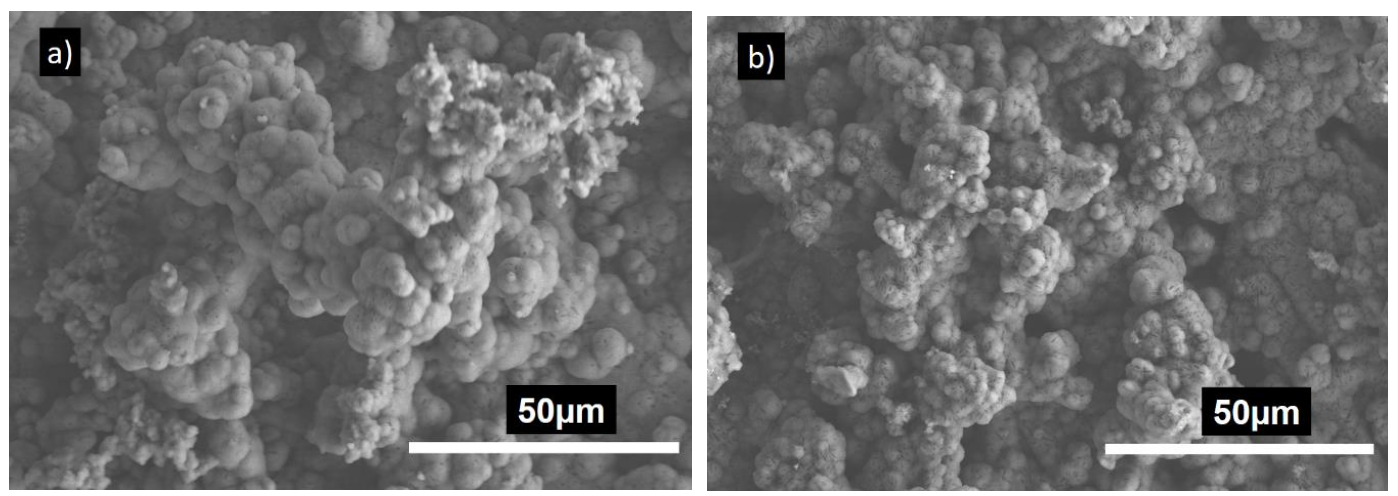

Figure 5. Cont. 

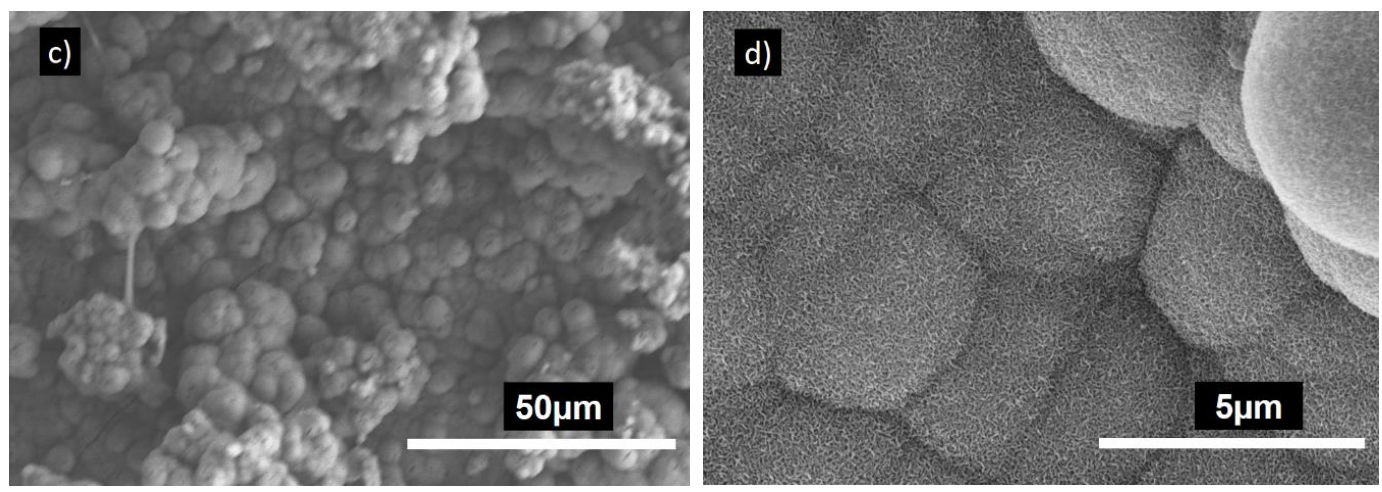

Figure 5. SEM images of (a) CPC-0 BT, (b,d) CPC-20 BT and (c) CPC-40 BT after 7 days immersion in $1.5 \times$ simulated body fluid $(\mathrm{SBF})$.

\subsection{Injectability}

All CPC formulations with and without BT showed good injectability without any filter pressing. The injectability of smart CPC-x BT pastes are presented in Figure 6. All compositions retained their injectability up to 5-6 min after starting to mix the powders and colloidal silica.

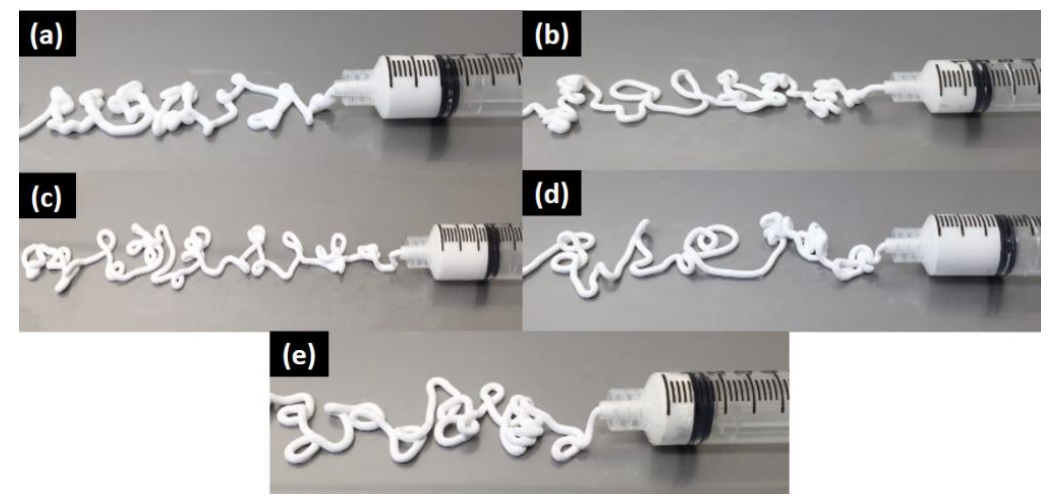

Figure 6. Injectability of smart CPC-x BT formulations where (a) $x=0$ wt $\%$, (b) $x=10$ wt $\%$, (c) $\mathrm{x}=20 \mathrm{wt} \%$, (d) $\mathrm{x}=30 \mathrm{wt} \%$, and (e) $\mathrm{x}=40 \mathrm{wt} \%$.

\subsection{Washout Resistance Test}

All CPC formulations injected into SLS solution showed excellent resistance against deterioration in a harsh environment created by SLS. No signs of disintegration were observed after keeping those in SLS for $5 \mathrm{~min}$. The images shown in Figure 7 show the absence of any degradation after 5 min signifying good washout resistance of the cement samples. The samples were held further in immersion for $24 \mathrm{~h}$ and after the specified time frame, no disintegration was observed.
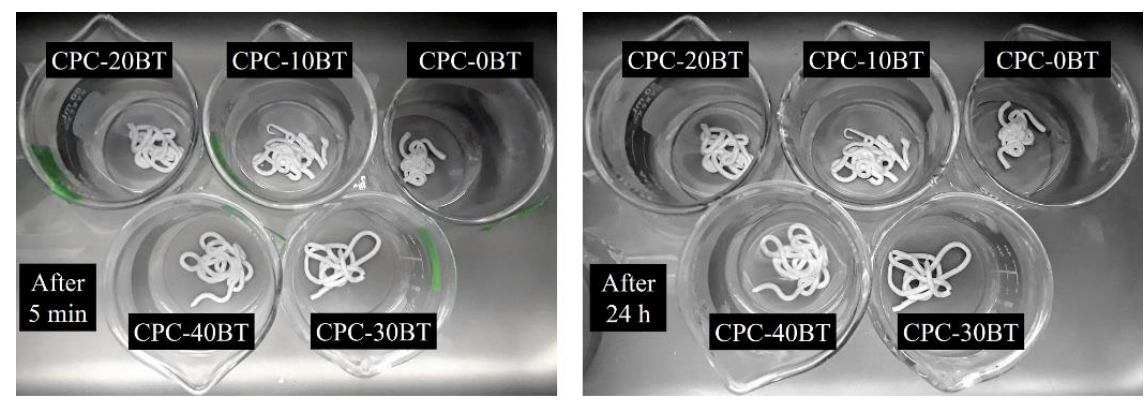

Figure 7. Washout resistance test of various CPC formulations in SLS. 


\subsection{Biodegradation}

Figure 8 shows the weight loss evaluation of various cement samples in vitro. The medium used for testing was $1.5 \times \mathrm{t}$-SBF and the results are expressed in terms of weight loss $\%$. For CPC samples with 0 and $20 \mathrm{wt} \% \mathrm{BT}$, weight loss rates are comparable with similar weight loss rate. Although no statistical difference was observed, $40 \mathrm{wt} \%$ samples showed comparatively less degradation rate as compared to 0 and $20 \mathrm{wt} \%$ samples.

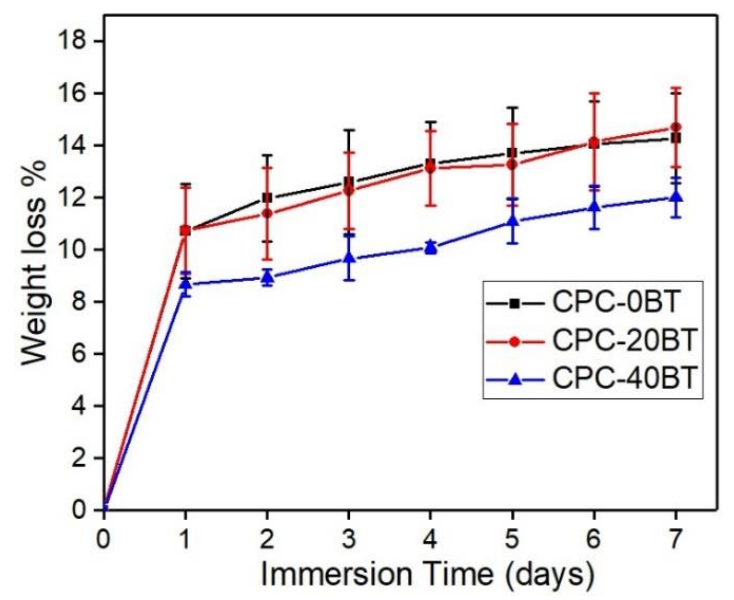

Figure 8. Weight loss $\%$ of CPC-x BT samples in $1.5 \times \mathrm{t}-\mathrm{SBF}$ at different points of time.

\subsection{Cytocompatibility}

The in vitro cell proliferation tests were carried out on 0,20 and 40 wt \% samples with pre-osteoblast OB-6 cells extracted from mice and the results are presented in Figure 9. Hydroxyapatite (HA) was used as a negative control for the cell studies. The number of cells is proportional to the optical density (OD) readings and thus the results are presented in terms of OD450 readings. After a $24 \mathrm{~h}$ period, the number of cells attached on CPC-20BT samples were observed to be lower $(p<0.05)$ as compared to CPC with 0 and $40 \mathrm{wt} \%$ samples. However, there were no significant difference $(p>0.05)$ in the number of cells attached when compared with the HA control. On the contrary, cell cultured with $40 \mathrm{wt} \%$ samples extracts showed significantly lower $(p<0.05)$ values than the rest of the CPC formulations and HA control extracts after a $72 \mathrm{~h}$ period. This implies that CPC-40 BT samples exhibited lower cytocompatibility with an increase of incubation time, as compared to CPC-20 BT, which helped in enhanced cell proliferation over $72 \mathrm{~h}$.

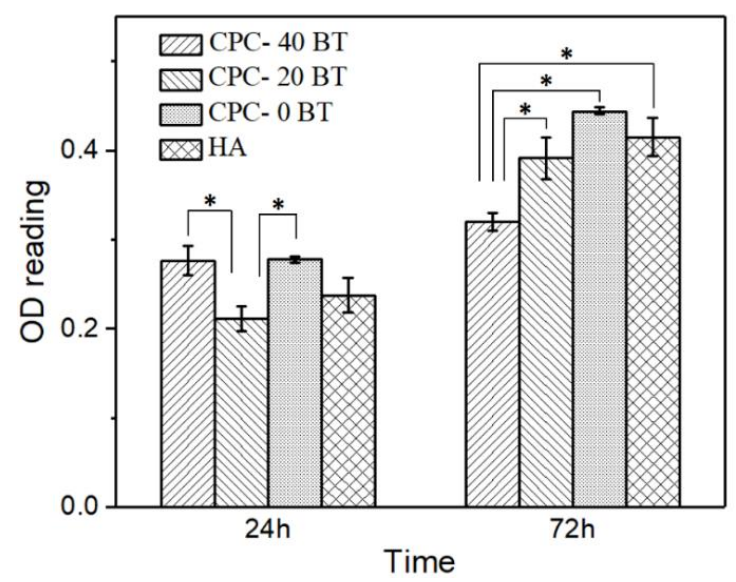

Figure 9. Optical density (OD) values of OB-6 pre-osteoblast cells seeded in extract of smart CPC-x BT formulations and HA for $24 \mathrm{~h}$ and $72 \mathrm{~h},{ }^{*}$ refers to statistically different pair $(p<0.05)$. 
The results from live and dead assay are presented in Figure 10 where the viable and dead cells are represented by green and red fluorescence respectively. The CPC-0 BT showed a relatively lower number of cells attachment and proliferation than smart CPC formulations with BT. Moreover, CPC-20/40 BT and the HA control had a comparable number of live cells attached to their surfaces implying higher cell proliferation on BT incorporated samples. This section is divided into subheadings to provide a concise and precise description of the experimental results, their interpretation, as well as the experimental conclusions that can be drawn.
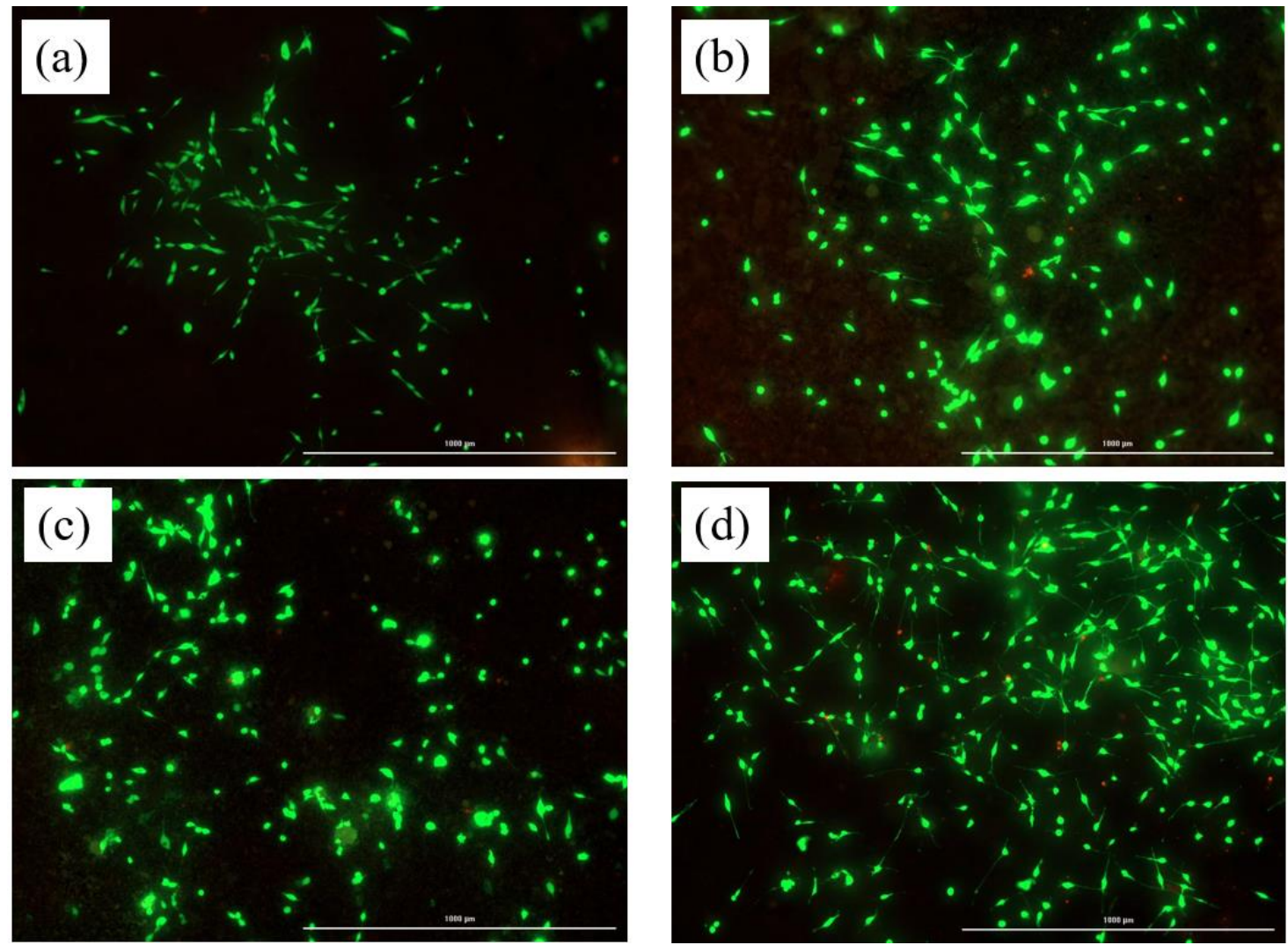

Figure 10. Live and dead cell assay for the cells attached and proliferating along the surface of (a) CPC-0 BT, (b) CPC-20 BT, (c) CPC-40 BT, and (d) HA surface at day 5. The viable cells are indicated by green fluorescence and dead cells by red fluorescence. Scale $1000 \mu \mathrm{m}$.

\section{Discussion}

Magnesium ion $\left(\mathrm{Mg}^{2+}\right)$ is the second most abundant intracellular divalent cation and has been known for its involvement in diverse cellular functions. Since $\mathrm{Mg}^{2+}$ assists in bone mineral metabolism, formation and the crystallization process, in addition to the $\mathrm{Ca}^{2+}$ ion, premixed powder (PMP) has been integrated with magnesium hydroxide $\left[\mathrm{Mg}(\mathrm{OH})_{2}\right]$ [43-45]. At the beginning of our study, setting time was measured by using $\mathrm{PMP}, \mathrm{MgO}$ as powder phase and colloidal silica as a liquid phase. This composition completely set within $3 \mathrm{~min}$ and did not allow sufficient working time as the ideal handling requirements for an injectable CPC are: initial setting time 3-8 min, cohesion time $\geq 1 \mathrm{~min}$, and final setting time $\leq 15 \mathrm{~min}[23,24]$. The setting time can be modified by adjusting the cement composition and incorporating additives such as sodium orthophosphates, citric acid, gelatinized starch [24], borax or sodium borate decahydrate $\left(\mathrm{Na}_{2} \mathrm{~B}_{4} \mathrm{O}_{7} \cdot 10 \mathrm{H}_{2} \mathrm{O}\right)$ [46], p-chitosan [29], surface-modified multi-walled carbon nanotubes [42], and colloidal silica [38]. The present study uses borax as a setting time retardant. After numerous trials, the optimal concentration of borax was identified to be $4 \mathrm{wt} \%$ as this resulted in initial and final setting times of approximately $8 \mathrm{~min}$ and 15 min respectively (Table 4). 
The setting mechanism of CPC is a continuous process and can be dissociated into two parts. First, the interaction between $\mathrm{Ca}^{2+}$ and $\mathrm{Mg}^{2+}$ with excess $\mathrm{H}_{2} \mathrm{PO}_{4}{ }^{-}$and $\mathrm{HPO}_{4}{ }^{2-}$, forms a network to provide initial stability, and is responsible for initial cement setting [38]. The second part involves the hardening mechanism via entanglement of the precipitated crystals and thus results in the final setting $[23,24]$. The relevant chemical reactions involved during setting can be summarized as:

$$
\begin{gathered}
\mathrm{Ca}(\mathrm{OH})_{2}+2 \mathrm{H}_{3} \mathrm{PO}_{4}+\mathrm{Mg}(\mathrm{OH})_{2}+\mathrm{Na}^{+}(\text {aq })+\mathrm{HCO}_{3}{ }^{-}(\text {aq })+\mathrm{Si}-\mathrm{OH}+\mathrm{Si}-\mathrm{OH} \\
\rightarrow \mathrm{CaHPO}_{4}(\text { active })+\mathrm{MgHPO}_{4} \cdot 3 \mathrm{H}_{2} \mathrm{O}(\text { active })+2 \mathrm{H}_{2} \mathrm{O}+\mathrm{Na}^{+}(\text {aq }) \\
+\mathrm{HCO}_{3}{ }^{-}(\text {aq })+\mathrm{Si}-\mathrm{O}-\mathrm{Si} \\
\mathrm{CaHPO}_{4}(\text { active })+\mathrm{MgHPO}_{4} \cdot 3 \mathrm{H}_{2} \mathrm{O}(\text { active })+\mathrm{H}_{2} \mathrm{O}+\mathrm{Si}-\mathrm{OH}+\mathrm{Si}-\mathrm{OH} \\
\rightarrow \mathrm{CaHPO}_{4}(\text { stabilized })+\mathrm{MgHPO}_{4} \cdot 3 \mathrm{H}_{2} \mathrm{O}(\text { stabilized }) \\
+ \text { amorphous phases }+2 \mathrm{H}_{2} \mathrm{O}+\mathrm{Si}-\mathrm{O}-\mathrm{Si}
\end{gathered}
$$

Generally, the infusion of BT within the cement samples lowers the overall concentration of active self-setting $\mathrm{CaHPO}_{4}$, accounting for reduced matrix entanglement which in turn increases the setting time. In addition, $\mathrm{BT}$ addition undermines the physical bond between plate-like monetite crystals resulting in reduced mechanical strength. Except $10 \mathrm{wt} \%$ BT samples, all the samples have trivial differences $(p>0.05)$ in the setting time values. Significant reduction of setting parameters for $10 \mathrm{wt} \%$ samples can be attributed to higher siloxane group formation (Figure 3) in these samples as indicated in our FTIR results. The self-hardening CPCs must exhibit a mechanical strength at least equivalent to trabecular bones i.e., $10 \mathrm{MPa}$ [24]. All as-prepared CPCs displayed strength higher than $15 \mathrm{MPa}$ proving their viability in orthopedic applications (Figure 1). Wolff et al. reported compressive strength of approximately $55 \mathrm{MPa}$ for an injectable bone cement consisting of monocalcium phosphate monohydrate, tricalcium phosphate, and calcium carbonate mixed with sodium phosphate solution [47]. Whereas a comparative study carried out by Dadkhah et al. reported compressive strength of injectable calcium sulphate cement (CSC), Spine-Ghost cement and Cerament ${ }^{\circledR}$ after $24 \mathrm{~h}$ to be $15.8 \mathrm{MPa}, 14 \mathrm{MPa}$, and $8.2 \mathrm{MPa}$ respectively. Comparing our data with Dadkhah et al., we can claim that our formulation is superior to CSS [48]. No detrimental effect on compressive strength occurs up to $40 \mathrm{wt} \%$ of BT addition. Up to $10.0 \mathrm{vol} \%$ (or $35 \mathrm{wt} \%$ ) BT content filled within PMMA bone cements, R.G. Carrodeguas et al. [21] reported an insignificant effect on ultimate compressive strength of cement. The subunits of colloidal silica particles are usually un-joined $\mathrm{Si}(\mathrm{OH})_{2}$. Initially $\mathrm{OH}^{-}$at the surface of colloidal silica particles assists in electrostatic dispersion of cement reactants among nanosilica particles $[38,41]$. The colloidal silica particles then interact together and polymerize into a $3 \mathrm{D}$ network of siloxane ( $\mathrm{Si}-\mathrm{O}-\mathrm{Si}$ ) groups forming a bond between as-produced DCPA, newberyite crystals, and incorporated BT simultaneously [41]. Therefore, colloidal silica condensation to siloxane via gelling mechanism [41] resisted the setting time increment and compressive strength decrement in our cement samples.

The prime constituent of PMP being $\mathrm{Ca}(\mathrm{OH})_{2}$ and $\mathrm{H}_{3} \mathrm{PO}_{4}$, the XRD analysis (Figure 2) shows major peaks for monetite. Also, due to the presence of $\mathrm{Mg}(\mathrm{OH})_{2}$ as a precursor, the newberyite peak was observed in the XRD results. $\mathrm{Mg}^{2+}$ and $\mathrm{Ca}^{2+}$ cations have similar chemical affinity; thus, formation of newberyite is anticipated. Newberyite is an important magnesium phosphate $(\mathrm{MgP})$ compound which has shown promising properties in several orthopedic applications. Thus, its presence would not harm the bioceramic performance [49]. Besides, MgPs in general are slowly gaining attention in the literature as the $\mathrm{CaO}-\mathrm{P}_{2} \mathrm{O}_{5}$ system [50]. Additional BT peaks in BT incorporated samples without any changes in the phases and crystal structure implies there is no undergoing chemical reaction involving BT in the samples. Our reaction system has a molar ratio of $(\mathrm{Ca}+0.5 \mathrm{Na}) / \mathrm{P}$ less than 1 (i.e., excess phosphoric acid), and consist of $\mathrm{Ca}^{2+}, \mathrm{Mg}^{2+}$, and $\mathrm{Na}^{+}$cations. Yet, $\mathrm{XRD}$ results did not show peaks of other phases such as $\mathrm{Ca}\left(\mathrm{H}_{2} \mathrm{PO}_{4}\right)_{2}, \mathrm{Mg}\left(\mathrm{H}_{2} \mathrm{PO}_{4}\right)_{2}, \mathrm{NaH}_{2} \mathrm{PO}_{4}$. Since microwave synthesis favors amorphous phases, other above mentioned phases might have formed amorphous compounds by partial transformation of $\mathrm{H}_{2} \mathrm{PO}_{4}{ }^{-}$and $\mathrm{HPO}_{4}{ }^{2-}$ ions with the available cations [51,52]. The SEM 
images (Figure 4) revealed the presence of large plate-like monetite crystals. The distribution of plate like crystals can be seen throughout the surface of 10 and $20 \mathrm{wt} \%$ BT samples. The plate-like monetite crystals have a capability of forming a network easily by interacting with each other. This network accelerates the initial stabilization of the cement and reduces the solidification time. Thus, although insignificant the $10-20 \mathrm{wt} \%$ of BT addition led towards a lower initial setting time. Furthermore, the surface morphology at higher magnification (Figure 4f) confirmed the infusion of BT within the CPC structure.

Incorporation of ferroelectric BT contributes towards the enhancement of the electrical properties of formulation simulating the actual bone scenario. Under stress conditions, BT generates electrical charges on the sample surfaces. Negative charges on the sample surface adsorbs $\mathrm{Ca}^{2+}$ cations which act as nuclei for the formation of the Ca-P layer [53]. $\mathrm{Ca}^{2+}$ cations also facilitate protein adhesion such as intergrins, fibronection, and osteonectin. On the other hand, limited apatite formation is expected from positive charges on the surface as they attract antiadhesive anionic groups such as $\mathrm{HPO}_{4}{ }^{2-}$ and $\mathrm{HCO}_{3}{ }^{2-}$ [54]. There are instances in the literature where apatite formation was accelerated by using a higher concentration of SBF [55]. The colloidal silica is also responsible for apatite nucleation and growth [56]. Even though the increment of apatite on SBF immersed BT incorporated samples was insignificant, these samples under in vivo stress conditions are expected to increase apatite formation as compared to CPC-0 BT.

As we are dealing with injectable cement, the more realistic evaluation of washout resistance is by injecting cement paste into SLS straight after loading into the syringe and therefore the tests were carried out following this approach. Magnesia, $\mathrm{MgO}$, enhances the anti-washout property of calcium phosphate cements. Moreover, the binding property of silica with CPCs and BT is also expected to improve the washout resistance. The washout resistances of monetite cement with and without chitosan in SLS as reported by Touny et al. [40] were $1 \mathrm{~h}$ and immediate dissociation into powder respectively. Our cement formulations have better washout resistance as all formulation maintained their shape even after $24 \mathrm{~h}$ (Figure 7).

Bone graft cements demand a combination of good injectability and proper hardness to minimize invasiveness of surgery [24]. It is noteworthy that the as-prepared CPCs formulations maintained proper injectability up to 5-6 min along with high workability and cohesion time. When compared to the commercially available Norian SRS ${ }^{\circledR}$ cements, present CPC formulation displayed superiority in terms of injectability. Norian SRS ${ }^{\circledR}$ cements exhibit filter pressing with $1.5 \mathrm{~mL}$ uninjectable cement out of $4.5 \mathrm{~mL}$ [24] whereas with $5 \mathrm{~mL}$ of our formulation paste inside the syringe, each of our compositions avoided this phenomenon. More often addition of fillers in CPCs reduces porosity causing slower resorption, slow bone substitution, poor injectability and other poor rheological properties [24]. On the contrary, in our work, the addition of BT as filler is promoting the bone substitution rate, while the injectability and degradation rate remained unaffected. However, the present CPC formulations have some porosity. The presence of pores in the formulations is mainly because of trapped air. It should also be noted that porosity, pore size, and interconnectivity of pores are important for cell penetration and bone ingrowth. R.G. Carrodeguas et al. [22] reported acceptable setting parameters, compressive strength, radiopacity, and injectability for surgical procedures with $20-50 \mathrm{wt} \%$ of untreated or silanated $\mathrm{BaTiO}_{3}$ or $\mathrm{SrTiO}_{3}$ in acrylic bone cements. The addition of $20-40 \mathrm{wt} \% \mathrm{BT}$ into our CaP structure is expected to provide sufficient radiopacity to the cement under fluoroscopy. While considering the biodegradability aspect, $\mathrm{BT} \leq 20 \mathrm{wt} \%$ in cement samples is more favorable.

In vitro cytocompatibility tests are crucial preliminary tests for biomaterials before moving forward to more complex and expensive in vivo experiments. Incorporating the right amount of dopant leads to multi-functionality in various orthopedic materials. Recently our group doped Ag into $\mathrm{CaPs}$ and MgPs to make antibacterial coatings using microwave irradiation $[57,58]$. The WST- 1 assay OD reading after $24 \mathrm{~h}$ revealed lowered number of cell attachment on $20 \mathrm{wt} \%$ samples than for 0 and $40 \mathrm{wt} \%$ samples, however, they were comparable to the HA control. The biocompatibility behavior of particulate filled composite can be different from its identical bulk composite [19]. This can be the 
plausible reason behind the low OD reading of $20 \mathrm{wt} \%$ samples as compared with $0 \mathrm{wt} \%$ samples. As a surprise, the initially inhibiting $20 \mathrm{wt} \%$ samples showed OD reading comparable $(p>0.05)$ to $0 \mathrm{wt} \%$ samples and HA control after $72 \mathrm{~h}$ period. Fine $(<2 \mu \mathrm{m})$ wear particles can translocate to the different organs via systemic circulation and lead to cell toxicity [19]. BT used in this study had a particles size of less than $2 \mu \mathrm{m}$. Therefore, the reduced OD values for $40 \mathrm{wt} \%$ samples after $72 \mathrm{~h}$ period can be due to the presence of excessive fine BT particles. This clearly indicates CPC-20 BT to be the optimum composition for biocompatible ferroelectric CPC cement. All the samples showed higher OD readings compared to the $24 \mathrm{~h}$ period implying cell proliferation on CPC-x BT samples. Furthermore, the live and dead cell assay after 5 days incubation clarified the non-toxic nature of cement samples incorporated with BT. Higher cell proliferation on CPC-20/40 BT sample as compared to CPC-0 BT thus implies the enhancement of earlier stage >osteogenesis.

\section{Conclusions}

Smart CaP cements incorporated with ferroelectric BT were synthesized using microwave energy and colloidal silica. The as-prepared CPCs were bioactive, biocompatible, and most importantly bio-degradable. All cement formulation behaved in a similar fashion regarding setting time, mechanical strength, bioactivity, injectability, and washout resistance. Moreover, based on the cytocompatibility and biodegradation rate, we conclude the most favorable CPC composition for better cell viability and biodegradation to be $20 \mathrm{wt} \%$ of BT. These promising physical, mechanical and biological characteristics of novel injectable piezoelectric CPCs makes them possible candidates for a new generation smart biodegradable CaP bone cement.

Author Contributions: S.B.B. conceived the idea and framework; N.K. and B.G. conducted experiments; N.K. and P.S. carried out data analysis; S.B.B., N.K. and P.S. wrote and reviewed the manuscript.

Funding: This work was supported by NSF Grant No. 1706513.

Conflicts of Interest: The authors declare no conflict of interest.

\section{References}

1. Fukada, E.; Yasuda, I. On the piezoelectric effect of bone. J. Phys. Soc. Jpn. 1957, 12, 1158-1162. [CrossRef]

2. Shamos, M.H.; Lavine, L.S. Piezoelectricity as a fundamental property of biological tissues. Nature 1967, 213, 267-269. [CrossRef] [PubMed]

3. Bassett, C.A.L. Biologic significance of piezoelectricity. Calcif. Tissue Int. 1967, 1, 252-272. [CrossRef]

4. Anderson, J.C.; Eriksson, C. Piezoelectric properties of dry and wet bone. Nature 1970, 227, 491-492. [CrossRef] [PubMed]

5. Marino, A.A.; Becker, R.O. Piezoelectric effect and growth control in bone. Nature 1970, 228, $473-474$. [CrossRef] [PubMed]

6. Marino, A.A.; Becker, R.O.; Soderholm, S.C. Origin of the piezoelectric effect in bone. Calcif. Tissue Int. 1971, 8, 177-180. [CrossRef]

7. Williams, W.S.; Breger, L. Piezoelectricity in tendon and bone. J. Biomech. 1975, 8, 407-413. [CrossRef]

8. Reddy, G.N.; Saha, S. Electrical and dielectric properties of wet bone as a function of frequency. IEEE Trans. Biomed. Eng. 1984, 296-303. [CrossRef] [PubMed]

9. Park, J.B.; Kenner, G.H. Effect of Electrical Stimulation on the Tensile Strength of the Porous Implant and Bone Interface. Biomater. Med. Devices Artif. Organs 1975, 3, 233-243. [CrossRef] [PubMed]

10. Park, J.B.; Kenner, G.H. Effect of electrical stimulation on the interfacial tensile strength and amount of bone formation. Biomater. Med. Devices Artif. Organs 1976, 4, 225-233. [CrossRef] [PubMed]

11. Park, Y.S.O.; Kenner, J.B.; Moore, G.H.; Myers, R.R.; Sauer, B.R. Dental Implant Fixation by Electrically Mediated Process I. Interfacial Strength. Biomater. Med. Devices Artif. Organs 1978, 6, 111-126. [CrossRef]

12. Park, J.B.; Young, S.O.; Kenner, G.H.; Von Recum, A.F.; Myers, B.R.; Moore, R.R. Dental Implant Fixation by Electrically Mediated Process II. Tissue Ingrowth. Biomater. Med. Devices Artif. Organs 1978, 6, $291-303$. [CrossRef] [PubMed] 
13. Park, J.B.; Von Recum, A.F.; Kenner, G.H.; Kelly, B.J.; Coffeen, W.W.; Grether, M.F. Piezoelectric ceramic implants: A feasibility study. J. Biomed. Mater. Res. A 1980, 14, 269-277. [CrossRef] [PubMed]

14. Park, J.B.; Kelly, B.J.; Kenner, G.H.; Von Recum, A.F.; Grether, M.F.; Coffeen, W.W. Piezoelectric ceramic implants: In vivo results. J. Biomed. Mater. Res. A 1981, 15, 103-110. [CrossRef] [PubMed]

15. Feng, J.; Yuan, H.; Zhang, X. Promotion of osteogenesis by a piezoelectric biological ceramic. Biomaterials 1997, 18, 1531-1534. [CrossRef]

16. Dubey, A.K.; Balani, K.; Basu, B. Multifunctional Properties of Multistage Spark Plasma Sintered HA-BaTiO -Based Piezobiocomposites for Bone Replacement Applications. J. Am. Ceram. Soc. 2013, 96, 3753-3759. [CrossRef]

17. Prakasam, M.; Albino, M.; Lebraud, E.; Maglione, M.; Elissalde, C.; Largeteau, A. Hydroxyapatite-barium titanate piezocomposites with enhanced electrical properties. J. Am. Ceram. Soc. 2017, 100, 2621-2631. [CrossRef]

18. Dubey, A.K.; Basu, B. Pulsed Electrical Stimulation and Surface Charge Induced Cell Growth on Multistage Spark Plasma Sintered Hydroxyapatite-Barium Titanate Piezobiocomposite. J. Am. Ceram. Soc. 2014, 97, 481-489. [CrossRef]

19. Dubey, A.K.; Thrivikraman, G.; Basu, B. Absence of systemic toxicity in mouse model towards $\mathrm{BaTiO}_{3}$ nanoparticulate based eluate treatment. J. Mater. Sci. Mater. Med. 2015, 26, 103. [CrossRef] [PubMed]

20. Dubey, A.K.; Kakimoto, K.I. Impedance spectroscopy and mechanical response of porous nanophase hydroxyapatite-barium titanate composite. Mater. Sci. Eng. C 2016, 63, 211-221. [CrossRef] [PubMed]

21. Carrodeguas, R.G.; V'zquez, B.; del Barrio, J.S.R.; de la Cal, A.M. Barium titanate-filled bone cements. I. Chemical, physical, and mechanical characterization. Int. J. Polym. Mater. 2002, 51, 591-605. [CrossRef]

22. Carrodeguas, R.G.; Lasa, B.V.; Del Barrio, J.S.R. Injectable acrylic bone cements for vertebroplasty with improved properties. J. Biomed. Mater. Res. B Appl. Biomater. 2004, 68, 94-104. [CrossRef] [PubMed]

23. Dorozhkin, S. Calcium orthophosphate cements for biomedical application. J. Mater. Sci. 2008, 43, 3028-3057. [CrossRef]

24. Dorozhkin, S.V. Self-setting calcium orthophosphate formulations. J. Funct. Biomater. 2013, 4, $209-311$. [CrossRef] [PubMed]

25. Constantz, B.R.; Barr, B.M.; Ison, I.C.; Fulmer, M.T.; Baker, J.; McKinney, L.; Goodman, S.B.; Gunasekaren, S.; Delaney, D.C.; Ross, J.; et al. Histological, chemical, and crystallographic analysis of four calcium phosphate cements in different rabbit osseous sites. J. Biomed. Mater. Res. A 1998, 43, 451-461. [CrossRef]

26. Klammert, U.; Reuther, T.; Jahn, C.; Kraski, B.; Kübler, A.C.; Gbureck, U. Cytocompatibility of brushite and monetite cell culture scaffolds made by three-dimensional powder printing. Acta Biomater. 2009, 5, 727-734. [CrossRef] [PubMed]

27. Tamimi, F.; Torres, J.; Bassett, D.; Barralet, J.; Cabarcos, E.L. Resorption of monetite granules in alveolar bone defects in human patients. Biomaterials 2010, 31, 2762-2769. [CrossRef] [PubMed]

28. Cama, G.; Gharibi, B.; Sait, M.S.; Knowles, J.C.; Lagazzo, A.; Romeed, S.; Di Silvio, L.; Deb, S. A novel method of forming micro- and microporous monetite cements. J. Mater. Chem. B 2013, 1, 958-969. [CrossRef]

29. Boroujeni, N.M.; Zhou, H.; Luchini, T.J.; Bhaduri, S.B. Development of monetite/phosphorylated chitosan composite bone cement. J. Biomed. Mater. Res. Part B 2014, 102, 260-266. [CrossRef] [PubMed]

30. Nominal Dimensions, Permissible Variations for Wirecloth of Standard Test Sieves; ASTM E11; ASTM International: West Conshohocken, PA, USA, 1995.

31. Time of Setting of Cements, Lime, Gypsum by Gillmore Needle; ASTM C266-89; ASTM International: West Conshohocken, PA, USA, 1993.

32. Jalota, S.; Bhaduri, S.B.; Tas, A.C. Effect of carbonate content and buffer type on calcium phosphonate formation in SBF solutions. J. Mater. Sci. Mater. Med. 2006, 17, 697-707. [CrossRef] [PubMed]

33. Åberg, J.; Pankotai, E.; Hulsart Billström, G.; Weszl, M.; Larsson, S.; Forster-Horvath, C.; Lacza, Z.; Engqvist, H. In vivo evaluation of an injectable premixed radiopaque calcium phosphate cement. Int. J. Biomater. 2011, 2011, 232574. [CrossRef] [PubMed]

34. Takagi, S.; Chow, L.C.; Hirayama, S.; Eichmiller, F.C. Properties of elastomeric calcium phosphate cement-chitosan composites. Dent. Mater. J. 2003, 19, 797-804. [CrossRef]

35. Wu, F.; Su, J.; Wei, J.; Guo, H.; Liu, C. Injectable bioactive calcium-magnesium phosphate cement for bone regeneration. Biomed. Mater. 2008, 3, 044105. [CrossRef] [PubMed] 
36. Wu, F.; Wei, J.; Guo, H.; Chen, F.; Hong, H.; Liu, C. Selfsetting bioactive calcium-magnesium phosphate cement with high strength and degradability for bone regeneration. Acta Biomater. 2008, 4, 1873-1884. [CrossRef] [PubMed]

37. Babaie, E.; Lin, B.; Goel, V.K.; Bhaduri, S.B. Evaluation of amorphous magnesium phosphate (AMP) based non-exothermic orthopedic cements. Biomed. Mater. 2016, 11, 055010. [CrossRef] [PubMed]

38. Zhou, H.; Luchini, T.J.; Boroujeni, N.M.; Agarwal, A.K.; Goel, V.K.; Bhaduri, S.B. Development of nanosilica bonded monetite cement from egg shells. Mater. Sci. Eng. C 2015, 50, 45-51. [CrossRef] [PubMed]

39. Ren, F.; Ding, Y.; Leng, Y. Infrared spectroscopic characterization of carbonated apatite: A combined experimental and computational study. J. Biomed. Mater. Res. Part A 2014, 102, 496-505. [CrossRef] [PubMed]

40. Touny, A.H.; Dawkins, H.; Zhou, H.; Bhaduri, S.B. Hydrolysis of monetite/chitosan composites in $\alpha$-MEM and SBF solutions. J. Mater. Sci. Mater. Med. 2011, 22, 1101-1109. [CrossRef] [PubMed]

41. Borhan, S.; Hesaraki, S.; Ahmadzadeh-Asl, S. Evaluation of colloidal silica suspension as efficient additive for improving physicochemical and in vitro biological properties of calcium sulfate-based nanocomposite bone cement. J. Mater. Sci. Mater. Med. 2010, 21, 3171-3181. [CrossRef] [PubMed]

42. Boroujeni, N.M.; Zhou, H.; Luchini, T.J.; Bhaduri, S.B. Development of multi-walled carbon nanotubes reinforced monetite bionanocomposite cements for orthopedic applications. Mater. Sci. Eng. C 2013, 33, 4323-4330. [CrossRef] [PubMed]

43. Ding, S.; Zhang, J.; Tian, Y.; Huang, B.; Yuan, Y.; Liu, C. Magnesium modification up-regulates the bioactivity of bone morphogenetic protein-2 upon calcium phosphate cement via enhanced BMP receptor recognition and Smad signaling pathway. Colloids Surf. B Biointerfaces 2016, 145, 140-151. [CrossRef] [PubMed]

44. Salimi, M.H.; Heughebaert, J.C.; Nancollas, G.H. Crystal growth of calcium phosphates in the presence of magnesium ions. Langmuir 1985, 1, 119-122. [CrossRef]

45. Rude, R.K.; Gruber, H.E.; Wei, L.Y.; Frausto, A.; Mills, B.G. Magnesium deficiency: Effect on bone and mineral metabolism in the mouse. Calcif. Tissue Int. 2003, 72, 32-41. [CrossRef] [PubMed]

46. Mestres, G.; Ginebra, M.P. Novel magnesium phosphate cements with high early strength and antibacterial properties. Acta Biomater. 2011, 7, 1853-1861. [CrossRef] [PubMed]

47. Wolff, K.D.; Swaid, S.; Nolte, D.; Böckmann, R.A.; Hölzle, F.; Müller-Mai, C. Degradable injectable bone cement in maxillofacial surgery: Indications and clinical experience in 27 patients. J. Craniomaxillofac. Surg. 2004, 32, 71-79. [CrossRef] [PubMed]

48. Dadkhah, M.; Pontiroli, L.; Fiorilli, S.; Manca, A.; Tallia, F.; Tcacencu, I.; Vitale-Brovarone, C. Preparation and characterisation of an innovative injectable calcium sulphate based bone cement for vertebroplasty application. J. Mater. Chem. B 2017, 5, 102-115. [CrossRef]

49. Sikder, P.; Bhaduri, S.B. Microwave Assisted Synthesis and Characterization of Single-Phase Tabular Hexagonal Newberyite, an Important Bioceramic. J. Am. Ceram. Soc. 2018, 101, 2537-2544. [CrossRef]

50. Ren, Y.; Sikder, P.; Lin, B.; Bhaduri, S.B. Microwave assisted coating of bioactive amorphous magnesium phosphate (AMP) on polyetheretherketone (PEEK). Mater. Sci. Eng. C 2018, 85, 107-113. [CrossRef] [PubMed]

51. Zhou, H.; Agarwal, A.K.; Goel, V.K.; Bhaduri, S.B. Microwave assisted preparation of magnesium phosphate cement (MPC) for orthopedic applications: A novel solution to the exothermicity problem. Mater. Sci. Eng. C 2013, 33, 4288-4294. [CrossRef] [PubMed]

52. Zhou, H.; Luchini, T.J.; Agarwal, A.K.; Goel, V.K.; Bhaduri, S.B. Development of monetite-nanosilica bone cement: A preliminary study. J. Biomed. Mater. Res. B Appl. Biomater. 2014, 102, 1620-1626. [CrossRef] [PubMed]

53. Park, Y.J.; Hwang, K.S.; Song, J.E.; Ong, J.L.; Rawls, H.R. Growth of calcium phosphate on poling treated ferroelectric $\mathrm{BaTiO}_{3}$ ceramics. Biomaterials 2002, 23, 3859-3864. [CrossRef]

54. Ohgaki, M.; Kizuki, T.; Katsura, M.; Yamashita, K. Manipulation of selective cell adhesion and growth by surface charges of electrically polarized hydroxyapatite. J. Biomed. Mater. Res. A 2001, 57, 366-373. [CrossRef]

55. Koju, N.; Sikder, P.; Ren, Y.; Zhou, H.; Bhaduri, S.B. Biomimetic coating technology for orthopedic implants. Curr. Opin. Chem. Eng. 2017, 15, 49-55. [CrossRef]

56. Hesaraki, S.; Alizadeh, M.; Borhan, S.; Pourbaghi-Masouleh, M. Polymerizable nanoparticulate silica-reinforced calcium phosphate bone cement. J. Biomed. Mater. Res. B Appl. Biomater. 2012, 100, 1627-1635. [CrossRef] [PubMed] 
57. Sikder, P.; Koju, N.; Ren, Y.; Goel, V.K.; Phares, T.; Lin, B.; Bhaduri, S.B. Development of single-phase silver-doped antibacterial CDHA coatings on Ti6Al4V with sustained release. Surf. Coat. Technol. 2018, 342, 105-116. [CrossRef]

58. Sikder, P.; Grice, C.R.; Lin, B.; Goel, V.K.; Bhaduri, S.B. Single-phase, Antibacterial Tri-Magnesium Phosphate Hydrate Coatings on Polyetheretherketone (PEEK) Implants by Rapid Microwave Irradiation Technique. ACS Biomater. Sci. Eng. 2018. [CrossRef]

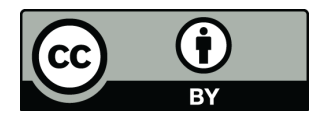

(C) 2018 by the authors. Licensee MDPI, Basel, Switzerland. This article is an open access article distributed under the terms and conditions of the Creative Commons Attribution (CC BY) license (http:/ / creativecommons.org/licenses/by/4.0/). 